\title{
ANALYSIS OF THE IMPACT OF SOCIAL MEDIA MARKETING ACTIVITIES IN BRAND LOYALTY WITH BRAND AWARENESS AS INTERMEDIATE VARIABLES (STUDY QN TRAVELDKA BRAND)
}

\author{
Rominda M Pasaribu', Andryana Silalahi² \\ Fakultas Ekanami Universitas HKBP Nommensen, Medan \\ megawati.pasaribu国gmail.com', andridksilalahi|
}

Info Artikel
Diterima : 14 April 2020
Revisi : 19 Mei 2020
Terbit : 20 Juni 2020

\section{Key wards:}

An Electronic Mouth To Mouth, Brand Image, Brand Loyalty

\section{Kata Kunci:}

Elektranik Dari Mulut Ke Mulut, Citra Merek, Loyalitas Merek

\section{Corresponding Authar :}

Raminda Pasaribu, E-mail : megawati.pasaribu回gmail.com

\section{Abstract}

Social media marketing is a process of strategy and methods for building the influence, reputation and brand of a company in the community of potential customers, readers, or supporters. Company. The objectives of this study are: (I) To examine the effect of sacial media marketing activities an brand loyalty on the Traveloka brand? (2) To test the effect of social media marketing activities on brand awareness of brands on the Traveloka brand, and (3) To examine the effect of sacial media marketing activities on brand loyalty and brand awareness as intermediary variables on the Traveloka brand? This study uses a survey method with primary data collection techniques. The research population is potential customers and the public who have seen social media marketing activities carried out by Traveloka Applications. The results showed that there was a significant influence between sacial media marketing activity variables on the Traveloka brand loyalty in Medan. There is a significant influence of sacial media marketing activity variables on the Traveloka brand awareness in Medan. There is a significant influence of social media marketing activity variables on the Traveloka brand awareness in Medan.

\section{Abstrak}

Pemasaran media sasial adalah proses strategi dan metode untuk membangun Pengaruh, reputasi dan merek sebuah perusahaan di kamunitas potensial pelanggan, pembaca, atau pendukung, perusahaan. Tujuan penelitian ini adalah: (I) untuk meneliti dampak dari aktivitas pemasaran media sasial pada loyalitas merek pada Traveloka merek? (2) untuk menguji efek dari kegiatan pemasaran media sacial merek sadar merek pada Traveloka, dan (3) untuk memeriksa efeknya tentang kegiatan pemasaran media sosial tentang kesetiaan merek dan kesadaran merek sebagai variabel perantara pada merek Traveloka? Penelitian ini menggunakan survei metode dengan teknik pengumpulan data primer. Populasi penelitian calon pelanggan dan masyarakat yang telah melihat pemasaran media sacial kegiatan yang dilakukan oleh aplikasi Traveloka. Hasilnya memperlihatkan bahwa di sana apakah pengaruh signifikan antara variabel aktivitas media sacial layalitas merek Traveloka di Medan. Ada pengaruh yang signifikan dari aktivitas variable sasial media pada kewaspadaan merek Traveloka di Medan. Ada pengaruh signifikan variabel aktivitas media sasial pada status merek Traveloka di Medan. 


\section{PENDAHULUAN}

Pesatnya perkembangan teknologi komunikasi yang semakin canggih, penggunaan internet sudah tidak asing lagi dalam hal memasarkan suatu produk melalui media sasial. Suatu usaha yang dilakukan untuk memasarkan barang dan jasa dengan menggunakan media internet yang dapat disebut dengan pemasaran secara elektronik ( $e$-marketing).Dengan adanya pemasaran secara elektronik (e-marketing) dapat menghemat biaya komunikasi pemasaran menjadi lebih efisien atau bahkan perusahaan tanpa mengeluarkan biaya apapun.Salah satu alat pemasaran secara elektronik adalah media $e$-marketing yang menjadi perbincangan yang hangat dan trend adalah melalui jejaring sasial (sacia/ media).Pemasaran media sasial yang dilakukan oleh perusahaan dengan menggunakan Facebouk, Twitter, Intagram, Youtabe dan lain-lain.

Salah satu usaha yang dapat dilakukan perusahaan untuk membangun loyalitas merek adalah melalui pemasaran media sasial. Menurut Neti (20II), yang mengatakan bahwa pemasaran sosial media adalah upaya untuk menggunakan media sosial yang bertujuan untuk membujuk konsumen kepada satu perusahaan, produk atatu jasa yang berharga. Pemasaran media sasial merupakan pruses strategis dan metodis untuk membangun pengaruh perusahaan, reputasi, dan merek dalam komunitas pelanggan potensial, pembaca atau pendukung. Layalitas merek memiliki 5 (lima) tingkatan kesetiaan terhadap merek. Yang pertama yaitu pembeli yang beranggapan bahwa semua merek sama. Sehingga merek hanya memiliki pean yang kecil dalam keputusan pembelian.Kedua, yaitu mereka yang merasa puas dengan produk yang telah mereka beli atau tidak dikecewakan oleh penjual.Ketiga, yaitu pembeli yang puas terhadap suatu produk dan disertai biaya untuk pindah yang cukup tinggi.Keempat, yaitu pembeli sudah sangat menyukai merek tersebut. Dan kelima, yaitu mereka sangat bangga menggunakan merek dan merekomendasikan kepada orang lain untuk menggunakan merek tersebut (Tandjung, 2004).

Keberhasilan pemasaran yang dilakukan dengan menggunakan media sasial menjadi bukti bahwa ruang gerak konsumen untuk mengenali produk atau jasa tertentu melalui cara-cara knnvensional, sehingga pemanfaatan media sasila khususnya internet menjadil jalan keluar dari permasalahan tersebut.Pemasaran melalui media sasial menunjukkan perkembangan yang signifikan karena selain murah, hemat waktu, mudah untuk digunakan dan mampu dipelajari oleh semua kalangan.Dengan adanya media internet, segala infarmasi dapat diakses secara mudah dan efisien.Hanya dengan mengunjuni web atau akun facebook, twitter, dan instagram maka dapat dengan mudah memperoleh informasi yang diinginkan oleh masyarakat atau pelanggan dan dapat menanyakan secara langsung kepada perusahaan sebagai penyedia informasi.Dengan adanya internet tidak ada lagi batas jarak dan waktu yang menjadi hambatan dalam memperoleh informasi. Hal ini sesuai dengan apa yang dikemukakan oleh Tritama dan Tarigan (2014) dalam pengaruh media sasial terhadap brand awareness produk perusahaan.

Salah satu perusahaan yang telah menggunakan media sasial sebagai sarana promosi dalam memasarkan produknya adalah Traveloka.Traveloka adalah perusahaan yang menyediakan layanan pemesanan tiket pesawat dan hotel secara daring dengan fokus perjalanan damestik di Indanesia.Travelaka melayani lebih dari 100.000 rute penerbangan dan 100.000 hatel di seluruh dunia. Selain itu, Travelaka juga dapat untuk memesan tiket kereta api dan pembelian pulsa.

Dalam beberapa tahun belakangan ini, Traveloka gencar memberikan promo harga untuk pelanggannya yang melakukan transaksi melalui aplikasi mabile.Strategi ini cukup berhasil menggiring masyarakat untuk mengunduh aplikasi mereka. Memasuki pertengahan 2017 ini, jumlah pengunduh aplikasi 
Traveloka berhasil meningkat hingga 50 persen. Bila tahun lalu baru diunduh sebanyak 10 juta, saat ini sudah mencapai 15 juta pengunduh, di mana mayoritasnya merupakan pengguna aktif.Berbagai promo menarik seperti diskon memang lebih banyak dihadirkan di aplikasi mabile.Penawaran ini membuat banyak pelanggan Traveloka beralih dari website ke aplikasi.Lebih dari 50 persen transaksi di Traveloka sudah bersumber dari aplikasi. saat ini Traveloka telah bekerja sama dengan 85 maskapai penerbangan yang melayani 100.000 rute di Asia Pasifik dan Eropa, serta 100.000 pilihan hotel yang ada di dalam dan luar negeri.Selain di Indanesia, sejak tahun 2015 Traveloka juga sukses mengembangkan bisnisnya ke lima negara di kawasan Asia Tenggara, yaitu Thailand, Singapura, Malaysia, Filipina dan Vietnam (www.traveloka.cam). Rumusan masalah dalam penelitian ini adalah: (I) Bagaimanakah pengaruh kegiatan pemasaran media sasial terhadap loyalitas merek pada merek Traveloka? (2) Bagaimanakah pengaruh kegiatan pemasaran media sosial terhadap kesadaran merek pada merek Traveloka? (3) Bagaimanakah pengaruh kegiatan pemasaran media sasial terhadap loyalitas merek dan kesadaran merek sebagai variabel perantara pada merek Traveloka?

\section{TINJAUAN PUSTAKA, PENELITIAN TERDAHULU DAN HIPOTESIS}

Menurut Kaplan dan Haenlein (20ID) defenisi pemasaran media sasial adalah sekelompak aplikasi yang berbasiskan pada internet dan dibangun berdasarkan kerangka pikiran, ideologi, dan teknologi dari platfarm web 2.D, medium ini dapat menghubungkan individu dengan individu untuk berbagi (sharing) dan berkumpul secara online. Menurut Rangkuti (2002) pemasaran media sasial adalah merupakan suatu proses perencanaan dan implemntasi dari sebuah konsep, harga, promosi, dan saluran distribui sehingga dapat terciptanya pertukaran suatu barang dalam rangka memuaskan kebutuhan pelanggan dan arganisasi secara bersamaan. Menurut Bilgin (2017) terdapat 5 (lima) indikator yang dapat digunakan untuk melihat aktivitas pada kegiatan pemasaran media sosial, yaitu: (1)Hiburan, (2)Interaksi, (3) Trendiness, (4)|klan, dan (5)Kustomisasi

Menurut Durianto (2004), loyalitas merek merupakan suatu ukuran keterkaitan pelanggan kepada sebuah merek, ukuran ini mampu memberikan gambaran tentang mungkin tidaknya searang pelanggan beralih ke merek praduk lain, terutama jika pada merek tersebut didapati adanya perubahan, baik menyangkut harga ataupun atribut lain. Durianto (2004) mengungkapkan untuk mengukur loyalitas merek dapat dilakukan dengan beberapa pendekatan diantaranya, pengukuran perilaku, pengukuran biaya peralihan, pengukuran kepuasan, pengukuran kesukaan terhadap merek dan pengukuran kamitmen. Menurut Fallon (20IZ) mengungkapkan terdapat 2 (dua) indikator dalam pengukuran layalitas merek, yaitu: (I) Kepuasan, (Z) Kesukaan pada merek, dan (3) Komitmen pada merek.

Kesadaran merek (brand awareness) adalah kesanggupan searang calon pembeli untuk mengenali, mengingat kembali suatu merek sebagai bagian dari aktegari produk tertentu.Menurut Aaker (1997) kesadaran merek adalah kemampuan pembeli pontensial untuk mengenali atau mengingat kembali suatu merek adalah anggata dari kategori produk tertentu, sedangkan menurut Kotler dan Keller (2009) menyatakan bahwa kesadaran merek adalah tentang kekuatan track atau crawd dalam ingatan konsumen yang mencerminkan kemampuan konsumen untuk mengingat atau mengenali merek dalam kondisi yang berbeda. Menurut Katler dan Keller (2009) kesadaran merek memiliki beberapa indikator, yaitu: (I) Konsumen paham seperti apa merek itu, (2) Dapat mengenali merek diantara merek pesaing, (3) Sadar akan keberadaan merek, (4) Konsumen membayangkan ciri merek dengan cepat, dan (5) Konsumen cepat mengenali logo atau simbol merek. 


\section{HIPOTESIS PENELITIAN}

\section{Pemasaran Media sosial pada Layalitas Merek}

Dengan adanya media sosial, perusahaan menjadi lebih aktif dalam melakukan kampanye dan promosi yang menguntungkan, konten yang popular, konten yang relevan, dan frekuensi yang mampu memperbaharui konten akan berpengaruh positif terhadap loyalitas merek (Endgormus dan Cicek, 20IZ). Loyalitas merek dapat diukur berdasarkan pengaruh merek, kepercayaan terhadap merek, sikap loyal, dan perilaku loyal. Dengan demikian maka hipotesis dirumuskan sebagai berikut:

HI: Kegiatan pemasaran dimedia sosial berpengaruh terhadap loyalitas merek

\section{Pemasaran Media Sosial pada Kesadaran Merek}

Tingkat kesadaran merek dari searang konsumen merupakan hal yang sangat penting bagi perusahaan untuk menyediakan praduk atau jasa yang benar-benar dibutuhkan. Untuk dapat menimbulkan kesadaran merek pada kansumen dibutuhkan suatu rangsangan atau stimulus atau hal-hal yang dapat merangsang munculnya kesadaran merek tersebut. Cara merangsang kesadaran merek yaitu dengan melakukan kegiatan promosi dan sosialisasi. Promosi dan sosialisasi dapat dilakukan perusahaan dengan menggunakan media sosial. Kegiatan pemasaran melalui media sosial sangat menguntungkan bagi perusahaan dikarenakan biaya yang murah dan konsumen dapat mengakses informasi dengan sangat mudah.Dengan demikian maka hipotesis dirumuskan sebagai berikut:

\section{H2: Kegiatan pemasaran dimedia sasia/ berpengaruhterhadap kesadaran merek}

\section{Pemasaran Media Sasial pada Layalitas Merek dan Kesadaran Merek Sebagai Variabel Perantara}

Terdapat beberapa studi yang menyatakan bahwa media sasial dapat memengaruhi kesadaran merek dan loyalitas merek dari searang konsumen (Anshari, 2013), strategi pemasaran melalui media sasial memliki pengaruh yang signifikan terhadap layalitas dan dapat membangun kesadaran merek.Menurut Aaker (1997) loyalitas merek adalah suatu ukuran keterkaitan searang pelanggan pada sebuah merek. Sedangkan menurut Assael (1995), layalitas merek didasarkan pada perilaku konsisten pelanggan untuk membeli sebuah merek sebagai bentuk proses pembelajaran pelanggan atas kemampuan merek dalam memenuhi kebutuhannya. Dengan demikian maka hipotesis dirumuskan sebagai berikut:

H3: Kegiatan pemasaran media sasial berpengaruh terhadap layalitas merek dengan kesadaran merek sebagai variabel perantara

Berdasarkan penjelasan diatas maka dapat digambarkan kerangka penelitian sebagai berikut:

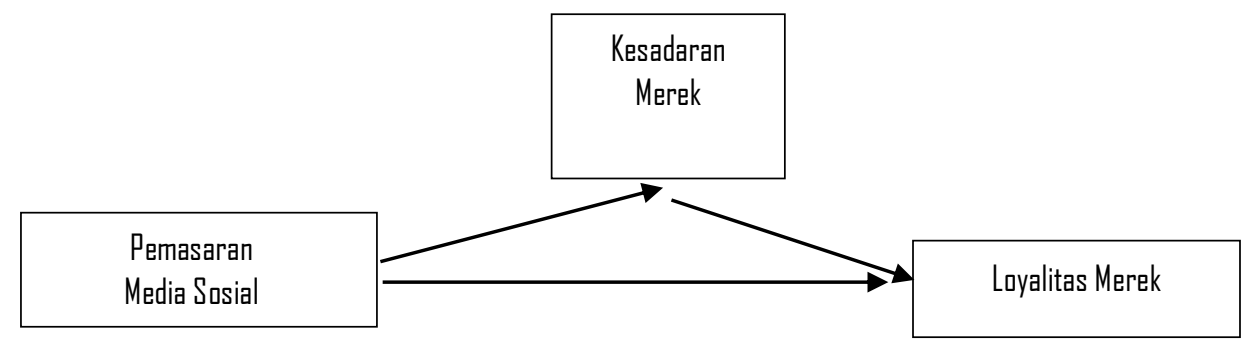

\section{Gambar I. Kerangka Penelitian}




\section{METODE PENELITIAN}

Metade penelitian yang digunakan adalah metade survei, dimana dalam pengumpulan data menggunakan instrumen kuesioner untuk mendapatkan tanggapan dari responden. Teknik pengumpulan data primer dilakukan dengan cara memberi seperangkat pertanyaan atau pernyataan tertulis kepada responden untukdijawab. Penelitian ini berlangsung selama 3 bulan dan lokasi penelitian yaitu di Kata Medan. Papulasi penelitian ini adalah calon konsumen potensial dan masyarakat yang pernah melihat kegiatan pemasaran media sasial yang dilakukan oleh Aplikasi Traveloka denganjumlah sampel yang digunakan dalam penelitian adalah 100 respanden.Teknik pengambilan sampel pada penelitian ini dilakukan dengan menggunakan metode purpasive sampling.

\section{Defenisi Operasional Variabel}

Defenisi operasional dalam penelitian ini dibangun berdasarkan 3 variabel yang digunakan dalam penelitian yaitu variabel kegiatan pemasaran media sasial (X), variabel layalitas merek (Y), dan variabel kesadaran merek (sebagai variabel perantara). Konstruks dalam penelitian ini diuraikan sebagai berikut:

\section{Tabel I. Defenisi Dperasional Variabel}

\begin{tabular}{|c|c|c|c|}
\hline No & Variabel & Indikator & Konstruk Pernyataan \\
\hline 1 & $\begin{array}{l}\text { Kegiatan } \\
\text { Pemasaran } \\
\text { Media Sosial }\end{array}$ & $\begin{array}{l}\text { 1. Hiburan } \\
\text { 2. Interaksi } \\
\text { 3. Trendiness } \\
\text { 4. Iklan } \\
\text { 5. Kustomisasi }\end{array}$ & $\begin{array}{l}\text { I. Akun media sasial dari merek Traveloka } \\
\text { 2angat menyenangkan } \\
\text { 2. Kanten yang dibagikan oleh media sasial } \\
\text { dari merek Traveloka menyenangkan } \\
\text { 3. Pembagian merek dari merek Traveloka } \\
\text { dimedia sasial menarik } \\
\text { 4. Pembagian infarmasi dimungkinkan dimedia } \\
\text { sasial pada merek merek Traveloka } \\
\text { 5. Diskusi dan pertukaran pendapata/opini } \\
\text { dimungkinkan pada laman media sasial dari } \\
\text { merek merek Traveloka } \\
\text { 6. Mengekspresikan pendapat/opini sangat } \\
\text { mudah pada laman media sasial merek } \\
\text { Traveloka } \\
\text { 7. Informasi yang dibagikan pada laman media } \\
\text { sasial dari merek merek Traveloka selalu } \\
\text { terbaru } \\
\text { 8. Penggunaan media sasial yang dilakukan } \\
\text { oleh merek Traveloka sangat trendi } \\
\text { 9. Saya sangat suka dengan iklan yang telah } \\
\text { dipublikasikan oleh merek Traveloka } \\
\text { 10. Iklan yang dirilis oleh merek Traveloka pada } \\
\text { laman media sasialnya sangat menarik }\end{array}$ \\
\hline
\end{tabular}

Analysis Uf The Impact Of Sacial Media Marketing Activities In Brand Loyalty With Brand Awareness As Intermediate Variables (Study Dn Traveloka Brand) 


\begin{tabular}{|c|c|c|c|}
\hline & & & $\begin{array}{l}\text { 11. Iklan pada laman media sasial merek media } \\
\text { sasial secara positif memengaruhi } \\
\text { perhatian saya terhadap merek Travelaka } \\
\text { 12. Infarmasi yang saya perlukan dapat saya } \\
\text { temukan diakun media sosial merek } \\
\text { Tarveloka } \\
\text { 13. Media sasial dari merek Travelaka } \\
\text { menyediakan informasi yang saya butuhkan } \\
\text { 14. Saya dapat dengan mudah memperoleh } \\
\text { informasi yang saya perlukan berkat } \\
\text { petunjuk diakun media sasial dari merek } \\
\text { Traveloka }\end{array}$ \\
\hline 2 & Loyalitas Merek & $\begin{array}{l}\text { 1. Kepuasan } \\
\text { 2. Kesukaan pada } \\
\text { merek } \\
\text { 3. Komitmen pada } \\
\text { merek }\end{array}$ & $\begin{array}{ll}\text { I. Saya merasa puas dengan merek yang } \\
\text { muncul pada laman media sasial Traveloka } \\
\text { 2. Saya biasanya menggunakan merek } \\
\text { Traveloka sebagai pilihan pertama saya } \\
\text { dibandingkan dengan merek lain } \\
\text { 3. Saya akan merekomendasikan merek } \\
\text { Traveloka kepada arang lain melalui media } \\
\text { sasial (facebaok, instagram, dan youtube) }\end{array}$ \\
\hline 3 & $\begin{array}{l}\text { Kesadaran } \\
\text { Merek }\end{array}$ & $\begin{array}{l}\text { 1. Pengenalan merek, } \\
\text { 2. Mengingat merek, } \\
\text { 3. Merek dalam } \\
\text { pikiran } \\
\text { 4. Merek dominan }\end{array}$ & $\begin{array}{l}\text { 1. Saya selalu sadar akan merek dari } \\
\text { Traveloka } \\
\text { 2. Saya sadar akan karakteristik merek } \\
\text { Travelaka } \\
\text { 3. Saya selalu bisa mengingat logo dari } \\
\text { Traveloka } \\
\text { 4. Merek Traveloka menjadi merek yang sangat } \\
\text { dominan bagi saya ketika akan memutuskan } \\
\text { untuk liburan }\end{array}$ \\
\hline
\end{tabular}

Analisis data dilakukan dengan menggunakan Structura/ Equatian Madeling (SEM) dengan Partia/ Least Square (PLS). PLS adalah analisis persamaan structural (SEM) berbasis varian yang secara simultan dapat melakukan pengujian madel pengukuran sekaligus pengujian madel structural.

\section{HASIL DAN PEMBAHASAN}

\section{Deskripsi responden berdasarkan usia}

Rentang usia responden dalam penelitian ini antara usia 19 tahun hingga 46 tahun. 


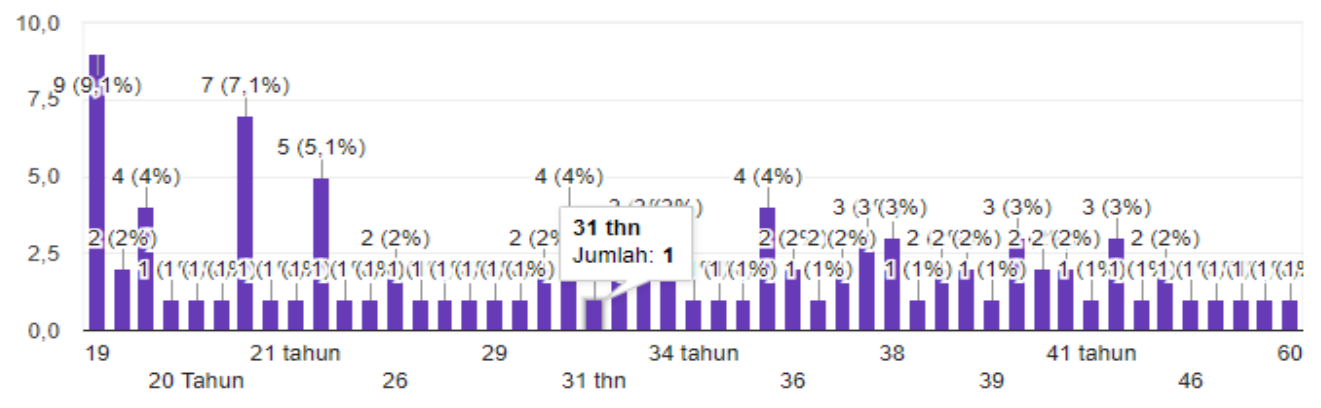

Gambar 2. Deskripsi Responden Berdasarkan Usia

\section{Deskripsi responden berdasarkan jenis kelamin}

Jumlah responden laki-laki sebesar 54,5\% dan jumlah responden perempuan sebesar 45,5\%. Dalam penelitian ini jumlah responden laki-laki lebih banyak dibandingkan dengan responden perempuan dengan selisih sebesar 9\%.

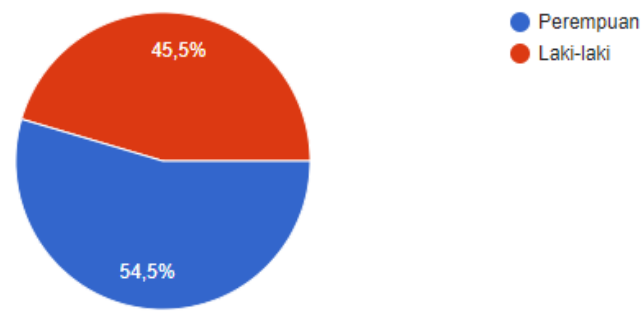

\section{Gambar 3. Deskripsi Responden Berdasarkan Jenis Kelamin}

\section{Pertanyaan apakah saudara pernah mendengar merek Traveloka?}

Pertanyaan terbuka yang pertama diajukan kepada responden dalam penelitian ini adalah "Apakah saudara pernah mendengar merek Traveloka?". Dari I00 kuesioner yang disebarkan 99\% responden pernah mendengar merek Traveloka dan hanya 1\% yang responden yang menjawab tidak pernah mendengar merek Traveloka. Jawaban responden dapat dilihat pada gambar berikut ini

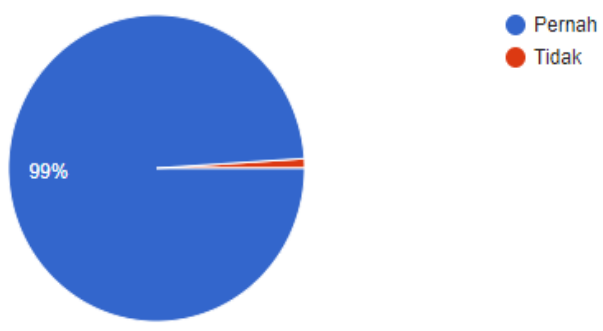

\section{Gambar 4. Apakah saudara pernah mendengar merek Traveloka?}

\section{Pertanyaan apakah saudara pernah melihat iklan di media sosial dari merek Traveloka?}

Jawaban responden dalam penelitian ini I00\% pernah melihat iklan dari merek Traveloka dimedia social seperti Facebook, Instagram, Aplikasi, Whatsapp, Twitter, dan lain-lain.

Gambar 5. Apakah saudara pernah melihat iklan di media sosial dari merek Travelaka?

Analysis Uf The Impact Of Sacial Media Marketing Activities In Brand Loyalty With Brand Awareness As Intermediate Variables (Study Dn Traveloka Brand) 


\section{Apakah saudara pernah mendengar merek Traveloka?}

Jawaban responden dalam penelitian ini adalah responden yang mendengar melalui media sasial Facebaok sebanyak 42,4\%, responden yang mendengar melalui media sosial Instagram sebanyak 15,2\%, responden yang mendengar melalui media sasial Youtube sebanyak 33,3\%, dan sisanya responden pernah mendengar melalui media lain seperti Televisi, Iklan pada Mobil, dan lain-lain.

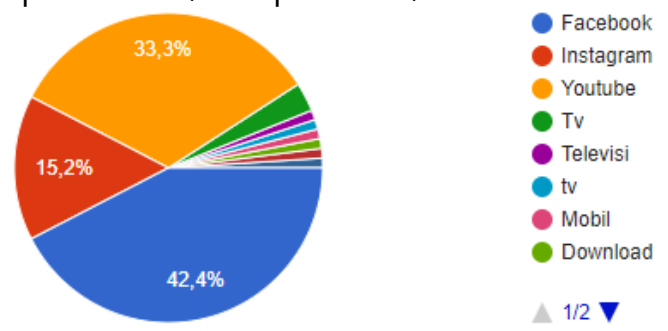

\section{Uji Kesesuaian Model (Model Fit Test)}

Gambar 6. Apakah saudara pernah mendengar merek Traveloka?

Dalam pengujian dengan menggunakan Structura/ Equation Madeling pada umumnya syarat yang digunakan untuk made/ fit adalah sebagai berikut:

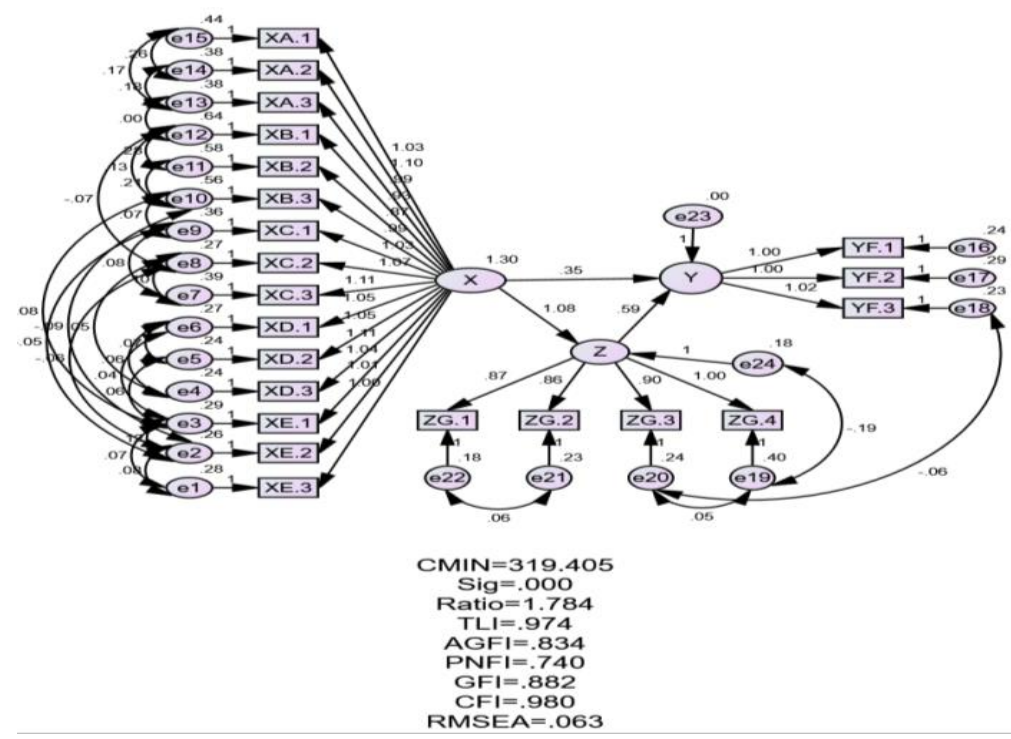

\section{Gambar 7 Uji Model Fit}

\section{Uji Hipotesis}

Hipatesis dalam penelitian ini diujikan dengan menggunakan nilai sig atau $p<0,05$. Nilai yang menunjukkan $\mathrm{p}<\mathrm{Q,Q5}$ adalah yang menunjukkan pengaruh yang signifikan. Selanjutnya nilai unstandardized va/ue yang diperoleh hanya menunjukkan pengaruh positif atau negatif dari hubungan antara 2 variabel. Berikut adalah hasil hipatesis sebagai berikut:

\section{Tabel 6. Hasil Uji Hipotesis}

\begin{tabular}{|c|c|c|c|c|c|}
\hline Variabel & $\begin{array}{c}\text { Pengaruh } \\
\text { Langsung }\end{array}$ & $\begin{array}{c}\text { Pengaruh Tidak } \\
\text { Langsung }\end{array}$ & $\begin{array}{c}\text { Cut Dff } \mathbf{p} \\
\mathbf{0 , 0 5}\end{array}$ & $\begin{array}{c}\text { Efak } \\
\text { Total }\end{array}$ & Keterangan \\
\hline$X \rightarrow Y$ & 0,346 & - & Signifikan & 0,346 & $H_{1}$ diterima \\
\hline$X \rightarrow Z$ & 1,078 & - & Signifikan & 1,078 & $H_{2}$ diterima \\
\hline
\end{tabular}




\section{\begin{tabular}{|c|c|c|c|c|c|}
\hline$X \rightarrow Y$ via $Z$ & 0,346 & 0,591 & Signifikan & 0,937 & $H_{3}$ diterima \\
\hline
\end{tabular}}

\section{Kegiatan pemasaran media sosial terhadap loyalitas merek}

Berdasarkan hasil uji hipotesis dalam penelitian ini dapat disimpulkan bahwa terdapat pengaruh yang signifikan antara variabel kegiatan pemasaran media sasial pada loyalitas merek Traveloka di Kota Medan atau HI diterima dengan nilai sebesar 0,346.

\section{Kegiatan Pemasaran Media Terhadap Kesadaran Merek}

Berdasarkan hasil uji hipotesis dalam penelitian ini dapat disimpulkan bahwa terdapat pengaruh yang signifikan antara variabel kegiatan pemasaran media sasial pada kesadaran merek Traveloka di Kota Medan atau H2 diterima dengan nilai sebesar 1,078.

\section{Kegiatan pemasaran media sosial terhadap loyalitas merek melalui kesadaran merek}

Berdasarkan hasil uji hipotesis dalam penelitian ini dapat disimpulkan bahwa terdapat pengaruh yang signifikan antara variabel kegiatan pemasaran media sasial pada kesadaran merek Traveloka di Kota Medan atau H3 diterima dengan nilai sebesar 0,937.

\section{PEMBAHASAN}

\section{Kegiatan Pemasaran Dimedia Sosial Pada Loyalitas Merek}

Hasil penelitian ini menunjukkan bahwa terdapat pengaruh yang positif dari kegiatan pemasaran media sasial terhadap loyalitas merek Traveloka dengan nilai yang cenderung kecil (0,346) dengan nilai signifikansi p = ૧,०००. Hal ini menunjukkan bahwa hipotesis yang diujikan dalam penelitian ini diterima.

Kegiatan pemasaran di media sasial tentunya mempengaruhi loyalitas merek Traveloka. Hal ini tentunya didukung bahwa Traveloka adalah sebuah perusahaan yang aplikasinya dapat diakses secara online. Perusahaan ini juga menyediakan jasa e-ticketing seperti tiket pesawat terbang, Kereta Api, Bioskap dan lain sebagainya. Travaloka juga merupakan aplikasi yang sering muncul pada iklan di media sasial seperti facebaok, instagram, youtube, twitter, dan lain-lain yang memberikan informasi mengenai tiket yang murah dan terjangkau.

Kegiatan pemasaran melalui media sasial ini memberikan dampak yang positif dan menciptakan positioning yang baik di masyarakat. Hal ini dilihat dari frekuensi iklan yang sering di media sasial yang menawarkan tiket yang murah dengan berbagai diskon. Selain itu, positioning merek dengan perusahaan startup e-ticketing pertama yang dikenal masyarakat memberikan kepercayaan merek dan pada ahirnya akan menciptakan loyalitas.

Penelitian ini didukung dengan penelitian yang dilakukan oleh Wandara dan Estri (2017). Hasil dari penelitian tersebut menunjukkan adanya pengaruh kegiatan media sasial terhadap layalitas merek dengan nilai p = 0.000, nilai kaefisien korelasi sebesar 0.64 dan koefisin determinan (RZ) sebesar 41.2\%, yang artinya terdapat pengaruh yang kuat antara variable kegiatan pemasaran media sosial terhadap layalitas merek.

\section{Kegiatan Pemasaran Dimedia Sosial Pada Kesadaran Merek}

Hasil penelitian ini menunjukkan bahwa terdapat pengaruh yang positif dari kegiatan pemasaran media sasial terhadap kesadaran merek Traveloka dengan nilai koefisien beta sebesar 1,078 dan nilai signifikansi p = १,QDl. Hal ini menunjukkan bahwa hipatesis yang diujikan dalam penelitian ini diterima.Kesadaran merek pada dasarnya adalah kemampuan konsumen untuk mengingat, mengidentifikasi, mengenali merek Traveloka. Traveloka menjadi salah satu perusahaan dengan merek e-ticketing yang terkenal. Hal ini tentunya memberikan 
kemudahan bagi konsumen untuk mengenali merek dengan cepat. Dengan adanya kegiatan pemasaran yang dilakukan Traveloka di media sasial yang menjadikan aksesibilitas informasi mengenai merek tersebut semakin mudah. Dalam penelitian ini pengaruh kegiatan pemasaran media sosial terhadap kesadaran merek memberikan pengaruh yang cukup besar. Tentunya hal ini dapat diindikasikan sebagai sudah tersebarnya dengan baik merek ini di kalangan masyarakat.

Penelitian ini didukung oleh penelitianlman, Arifin, Mawardi (2015), yang menemukan bahwa variabel brand expasure berpengaruh namun tidak signifikan terhadap kesadaran knnsumen, dihasilkan dengan nilai $\mathrm{t}$ hitung sebesar 0,137 dan nilai sig 0,891. Variabel custamer engagement berpengaruh signifikan terhadap kesadaran knnsumen dihasilkan dengan nilai $t$ hitung sebesar 2,251 dan nilai sig 0,026. Variabel electranic ward af mouth berpengaruh paling signifikan terhadap kesadaran konsumen, dihasilkan dengan nilai t hitung sebesar 5,172 dan nilai sig 0,000.

\section{Kegiatan Pemasaran Dimedia Sosial Pada Loyalitas Merek Melalui Kesadaran Merek}

Hasil penelitian ini menunjukkan bahwa terdapat pengaruh yang positif dari kegiatan pemasaran media sosial terhadap loyalitas merek melalui kesadaran merek dengan nilai koefisien beta sebesar 0,937 dan nilai signifikansi p = 0,000. Hal ini menunjukkan bahwa hipotesis yang diujikan dalam penelitian ini diterima. Kegiatan pemasaran di media sasial terhadap loyalitas merek memberikan pengaruh langsung sebesar 0,346. Jika dibandingkan dengan pengaruh tidak langsungnya yang memberikan pengaruh lebih besar yaitu 0,59 Il sehingga pengaruh total adalah sebesar 0,937.

Kegiatan pemasaran di media sasial tentunya memberikan dampak yang positif terhadap layalitas merek tetapi hal tersebut ternyata tidak cukup. Berdasarkan hasil penelitian yang diperoleh ternyata pengaruh tidak langsung melalui kesadaran merek akan memberikan dampak yang lebih besar. Hal ini menunjukkan bahwa perlunya kesadaran merek yang baik dari masyarakat untuk meningkatkan loyalitas terhadap merek Traveloka. Kegiatan iklan, diskan, dan lain-lain, ternyata tidak memberikan dampak yang terlalu besar. Perlu bagi konsumen untuk menimbulkan kesadaran merek yang lebih tinggi sehingga tercipta loyalitas merek yang baik.

\section{PENUTUP}

\section{Kesimpulan}

Kesimpulan dalam penelitiani ini adalah sebagai berikut: (I) Berdasarkan hasil uji hipatesis dalam penelitian ini dapat disimpulkan bahwa terdapat pengaruh yang signifikan antara variabel kegiatan pemasaran media sasial pada layalitas merek Traveloka di Kata Medan atau HI diterima dengan nilai sebesar 0,346, (2) Berdasarkan hasil uji hipotesis dalam penelitian ini dapat disimpulkan bahwa terdapat pengaruh yang signifikan antara variabel kegiatan pemasaran media sasial pada kesadaran merek Traveloka di Kata Medan atau HZ diterima dengan nilai sebesar 1,078., dan (3) Berdasarkan hasil uji hipatesis dalam penelitian ini dapat disimpulkan bahwa terdapat pengaruh yang signifikan antara variabel kegiatan pemasaran media sasial pada kesadaran merek Traveloka di Kota Medan atau H3 diterima dengan nilai sebesar 0, 437.

\section{Saran}

Berdasarkan hasil penelitian ini dapat dilihat bahwa ketiga variabel yang diuji memiliki hubungan yang pasitif baik secara langsung maupun tidak langsung, maka perusahaan Traveloka melihat ini sebagai sesuatu yang pasitif juga dengan melihat penelitian ini sebagai bahan masukan untuk pengambilan keputusan dalam 
menentukan proses promosi yang akan dilakukan dimasa yang akan datang. Kegiatan promosi yang dilakukan merek Traveloka saat ini sudah sangat baik namun tetap harus lebih memperhatikan kebutuhan dan keinginan dari knnsumen dan memanfaatkan teknologi yang ada untuk memudah para konsumen dalam mengakses proses pencarian informasi mengenai merek Traveloka.

\section{DAFTAR PUSTAKA}

Aaker, David A, 1997, Building Strung Brands. New York: Free Pres

Anshari, Shahriar, 2013, The Affect DF Sales Pramation Dn Cansumer Interest To Purchase In Ikca Autamative Company.

Assael, Henry, 1995, Custumer Behaviar And Marketing Action, Keat Publishing Company, Baston.

Bilgin, I, 2017, The Effect of Guided Inquiry Instructions a Caoperative Learning Approach on University Students Achievement of acid and Bases Cancept and Attitude Taward Guided Inquiry Instruction. Academic journals.

Durianto, D., Sugiarto, \& Sitinjak, T, 2004, Strategi Menaklukkan Pasar Melalui Riset Ekuitas dan Perilaku Merek. Jakarta: PT. Gramedia Pustaka Utama.

Erdogmus g Cicek, 2012, The Impact of Sacial Media Marketing on Brand Layalty. Journal of Social and Behavioral Sciences, 58, 1353-1360.

Fallon, 2012, Juicing The Drange (How 2 Turn Creativity Into A Pawerfull Business Advantange). Harvard Business School Press.

Iman, Arifin, Mawardi, 2015, Pengaruh Pemasaran Melalui Media Sasial Terhadap Kesadaran Kansumen Pada Praduk Internasional (Studi Pada Pengguan Praduk Uniqla di Indanesia). Jurnal Admistrasi Bisnis (JAB)/ Vol. Z4.No. I Juli 2015.

Kaplan. A.M \& Haenlein.M., 20I0, User of The World, unit! The callenges and apportunities of Sacial Media. Business Horizons 53.

Kotler dan Keller, 2009, Manajemen Pemasaran, dilid I, Edisi Ke I3 Jakarta. Erlangga

Neti, Sisira, 20II, Sacial Media And lts Rale Marketing in India.

Rangkuti, Freddy, 2002, Measuring Lustomer Satisfaction, Penerbit PT Gramedia Pustaka Ltama, Jakarta.

Tandjung, 2004. Marketing Management: Pendekatan Pada Nilai-Nilai Pelanggan, Edisi Kedua. Penerbit Bayumedia, Malang.

Triatma, Ilham Nur, 2016, Minat Baca Pada Siswa Kelas VI Sekulah Dasar Negeri Delegan 2 Prambanan Sleman Yogyakarta. E-Jurnal Prodi Teknologi Pendidikan. Vol. V Nomor 6.

Wandara dan Estri, 2017, Pengaruh Pemsaran Media Sosial Terhadap Layalitas Merek (Survey Pelanggan Pada Delima Hijab Bandung). Prosiding Manajemen.Universitas Islam Bandung. , website traveloka, www.traveloka.id, diaskes pada pada Q2 पktober 2018 